\title{
METHODOLOGICAL CHANGES AND CHALLENGES IN THE MEASUREMENT OF FREEDOM OF INFORMATION. AN ANALYSIS OF THE REPORTERS WITHOUT BORDERS AND FREEDOM HOUSE INDEXES
}

\author{
Ruth de Frutos \& Diego Giannone
}

\begin{abstract}
The article analyses the main methodological challenges of the two most important indicators in measuring freedom of the press around the world. Freedom House (FH) and Reporters Without Borders (RWB) have become references for studies that go beyond freedom of the press and their importance forces us to analyze what the methodological aspects are that determined these methodologies and which are omitted. The results of this study make it possible to determine that the indicators of Reporters Without Borders and Freedom House present serious methodological deficiencies that, although they have tried to correct, continue to be the source of numerous controversies, such as the absence of mechanisms to protect journalists in their measurement instruments.
\end{abstract}

KEYWORDS

Indicators; freedom of information; Freedom House; methodology; Reporters Without Borders

\section{Resumo}

$\mathrm{O}$ artigo analisa os principais desafios metodológicos colocados pelos dois indicadores mais importantes para medir a liberdade de imprensa no mundo. Freedom House (FH) e Repórteres Sem Fronteiras (RSF) tornaram-se referência para estudos que vão além da liberdade de imprensa, e sua importância nos obriga a analisar os aspetos metodológicos que determinam essas metodologias e que são omitidos. Os resultados deste estudo, ao analisar-se a avaliação dos países latino-americanos nos índices RSF e FH, nos permitem determinar que esses instrumentos apresentam graves deficiências metodológicas que, embora se tenham tentado corrigir, continuam a ser fonte de inúmeras controvérsias, como a ausência de mecanismos de proteção dos jornalistas em seus instrumentos de medição.

PALAVRAS-CHAVE

Indicadores; liberdade de imprensa; Freedom House; metodologia, Repórteres Sem Fronteiras

\section{INTRODUCTION}

Since the 1980 s there has been an exponential growth of indexes aimed at measuring a state's performance. Issues such as economic freedom, competitiveness, business environment, creditworthiness, democracy, corruption, and transparency have become central topics of several global benchmarks produced by international institutions, 
governmental and non-governmental organizations, and private actors. Among these factors, freedom of information has been - together with freedom - the main focus of Freedom House $(\mathrm{FH})$, with its annual publication of the Freedom of the Press Index $(\mathrm{FPI})$. For over twenty years, this instrument has been practically the sole measurement of global media freedom. Only in recent years has a new instrument been created by Reporters Without Borders (RSF): the Worldwide Press Freedom Index (WPFI). However, how do these indexes differ? And what do they look like? What conception(s) of freedom of information do they measure and promote? And in what ways does the use of one index influence our perception of the level of freedom of information in the world? The paper aims to address these issues by proposing an in-depth analysis of the theoretical and methodological aspects of the two instruments and focusing on two specific problems: the security of media practitioners and the way in which the two instruments measure freedom of information in Latin America.

The safety of journalists is one of the main concerns of the United Nations (UN) in recent years', but it is extremely difficult to quantify. In fact, organizations that measure freedom of expression and the right to information introduce aggressions suffered by journalists in their indicators in a diffuse manner, giving priority to qualitative analysis rather than quantitative data. This hypothesis requires a detailed study of two of the main instruments, the FPI and the WPFI.

Press freedom and media development have been the source of numerous studies on an international scale (Unesco, 2017). However, the academy has shown an irregular interest in the measurement tools that are used to measure these parameters (Becker, Vlad \& Nusser, 2007; Holtz-Bacha, 2011) and, especially, which are the aspects that are methodologically addressed in these measurements.

This research critically analyses two of the best-known measurement instruments, such as those developed by RSF and $\mathrm{FH}$. In particular, the present investigation observes how RSF and FH analyse various parameters, among which includes, due to its seriousness, the safety of journalists. "When journalists are targeted, societies as a whole also pay the price. The kind of news that gets silenced - corruption, conflicts of interest, illegal trafficking - is exactly the kind of information the public needs to know" (Guterres ${ }^{2}, 2017$ ).

Based on previous studies on the ideological and conceptual structure of these indicators (de Frutos, 2014; Giannone, 2014; Giannone \& de Frutos, 2016), the decision was made to analyse the approach of the methodologies of the indicators of RSF and $\mathrm{FH}$ in a particular region, such as Latin America. The aim of this research is to detect not only the changes in the methodological structure of these classifications, but also how it affects the particular cases of the nations of the region.

\footnotetext{
'Just to give an example, the United Nations Security Council has adopted eight resolutions on the safety of journalists. "Since 2012, eight resolutions on the safety of journalists have been passed by various UN bodies. Together, they provide a framework for the promotion of the safety of journalists at the global level, and, more importantly, at the national and local level. Four resolutions were passed by the UNGA, three by the HRC, one by the UNSC and another by Unesco. Previous to 2012, only two resolutions were focused on this particular issue; one passed by Unesco in 1997 and another, by the UNSC, in 2006. Resolutions are available in the six official UN languages: Arabic, Chinese, English, French, Russian and Spanish" (IFEX, 2017). Since 2013 on November 2 is the International Day to end impunity for crimes against journalists.

${ }^{2}$ Statement From UN Secretary General António Guterres, On 2 November 2017, The Day United Nations General Assembly Resolution 68/163 Designated To Be The International Day To End Impunity For Crimes Against Journalists.
} 
Nearly 50 journalists have been killed or "disappeared" for practicing their profession in Latin America during the $21^{\text {st }}$ century. Since 2000, aggressions have not only decreased with the establishment of new democratic systems, but have intensified in complex national contexts characterized by violence, the actions of multiple perpetrators as well as impunity. This dramatic situation has become a priority line for international organizations in recent years (Badran, 2017; Hughes et al., 2017), especially since the preparation of the UN Plan of Action on the Safety of Journalists and the Issue of Impunity 3 (UN, 2012).

The sustainable development goals, which make up the 2030 Program for Sustainable Development, set out the creation of measures to "promote peaceful and inclusive societies for sustainable development, provide access to justice for all and build effective, accountable and inclusive institutions at all levels" (Goal 164), which also highlights the protection of fundamental freedoms and public access to information. The safety of journalists and the elimination of impunity for human rights violations are fundamental components for achieving those goals ${ }^{5}$.

\section{LITERATURE REVIEW AND STATE OF THE ART}

Several studies use the FPI for their analyses. Some scholars have used it in efforts to identify new correlations between media freedom and democracy (Dahl, 2003), as well as to analyze the role of free press in promoting democratization, good governance and human development (Norris, 2006). Other studies used the FPI for testing the diffusion of media freedom (Sobel, Dutta \& Roy, 2011), as well as the empirical relationship between human rights and governance (Kaufmann, 2005), free press and corruption (Brunetti \& Weder 2003; Freille, Haque \& Kneller, 2007), press freedom and democratic peace (Van Belle, 1997). The FPI ratings and rankings figure in political debate, in a broad range of foreign policy, journalism, and aid-decision making all over the world. World Bank researchers have used them when drafting papers that help determine how much aid a country receives. UN agencies, national and private aid organizations use the index in programming hundreds of millions of dollars of media development funding. The FPI is one of the sources of the United Nations Development Programme handbook of good governance (UNDP, 2004), as well as one of the indicators used by the American government to determine country eligibility for the Millennium Challenge Corporation (MCC)

\footnotetext{
${ }^{3}$ The UN Plan of Action on the Safety of Journalists and the Issue of Impunity was endorsed by the UN Chief Executives Board on 12 April 2012. The Plan was prepared during the 1st UN Inter-Agency Meeting on this issue, convened by the Director General of Unesco at the request of the Intergovernmental Council of the International Programme for the Development of Communication (IPDC). More information at http://www.unesco.org/new/en/communication-and-information/ freedom-of-expression/safety-of-journalists/un-plan-of-action/

${ }^{4}$ More information at https://sustainabledevelopment.un.org/sdg16

${ }^{5}$ Developing tools to measure the safety of journalists in response to sustainable development goal (SDG)'s 16.10.1: "number of verified cases of killing, kidnapping, enforced disappearance, arbitrary detention and torture of journalists, associated media personnel, trade unionists and human rights advocates in the previous 12 months"
} 
program assistance 6 . Reporters and columnists employ it in discoursing on media freedom and diplomats in bringing pressure on governments that rank low on the index.

Previous studies on the FPI include a comparative analysis both of the evaluators of freedom of information (Burgess, 2010), and the instruments (Becker et al. 2007), as well as the possibility and utility of such global comparisons (Holtz-Bacha, 2011). Some analysis focused on the influence of using alternative press freedom indexes in determining the relationship between development and press freedom (Tran et al., 2011). Critics of the FPI underlined incorrect scaling and some methodical difficulties (Becker, 2003). Furthermore, $\mathrm{FH}$ is sometimes accused of having a pro-American bias (Chomsky \& Herman, 1988; Giannone, 2010; ONU, 2001; Scoble \& Wiseberg, 1981). Lastly, an in-depth analysis of the indicators of the FPI and their interplay with neoliberalism has been made (Giannone, 2014), and the political and ideological implications of the use of this instrument have been emphasized.

For its part, the Reporters Without Borders analysis has been used by various nongovernmental organizations, such as Unesco, which produced a Safety guide for journalists: a handbook for reporters in high-risk environments together with the NGO (Unesco \& RSF, 2015). The research of the organization itself has been used by academics (Díaz Nosty, 2016a) to assess the situation of the journalism profession in Latin America, taking into account the high level of impunity in these countries. Finally, the numerous methodological changes of RSF have been the source of academic discussions (de Frutos, 2014; Díaz Nosty \& de Frutos, 2017; Sapiezynka \& Lagos, 2016), in which some methodological controversies were highlighted.

\section{THEORETICAL FRAMEWORK}

"The mass communications media are the connective tissue of democracy. They are the principal means through which citizens and their elected representatives communicate in their reciprocal efforts to inform and influence" (Gunther \& Mughan, 2000, p. 1). Nevertheless, the literature in social and political science is notable for the almost general absence of rigorous comparative analyses of the mutually influencing interaction between freedom of information, on the one hand, and the basic democratic character of political regimes, on the other (for an exception see Voltmer, 2013).

What is freedom of information? According to Holtz-Bacha (2011, p. 130), "press freedom is understood differently in various parts of the world" and "even established democracies do not interpret press freedom in exactly the same way".

Early definitions of press freedom focused primarily on freedom from governmental control (Siebert et al. 1956). This classical liberal perspective on media freedom can be differentiated from the radical democratic one.

\footnotetext{
${ }^{6}$ The Millennium Challenge Corporation is an independent US foreign aid agency created by US Congress in 2004 with the aim to fight against global poverty, by delivering foreign assistance to eligible countries. For a list of the indicators see http://www.mcc.gov/pages/selection/indicators
} 
Within the classical liberal perspective (...) is a 'strand' arguing that the media should serve to protect the individual from the abuses of the state. Within the radical democratic perspective (...) is a 'strand' that argues that the media should seek to redress the imbalances in society. (Becker et al., 2007, p. 6)

These two definitions give rise to two different models of information: the liberal model and the social responsibility model 7 (Hallin \& Mancini, 2012). They are ideal types, and the media systems of individual countries fit them only roughly. Each model has an internal evaluative point of view and assigns a different role to press freedom.

The liberal model of information is characterized by a relative dominance of market mechanisms and of commercial media. This model distinguishes itself for its tendency to consider the media as an economic enterprise and the market as the natural arena for its development. This classical understanding of information has been strongly influenced by the rise of neoliberalism and its recalling of the ideal of a free market of ideas (Mirowski, 2011). According to this ideal, diversity manifests itself through competition between enterprises, and through freedom of choice. Information is thus primarily intended as a commodity. The Market is in charge of a regulation mechanism that must guarantee a satisfying economic balance between the supply and demand of information. Freedom of the press is as thus more guaranteed the less the State intervenes in the regulation and control of the media system. From a neoliberal perspective, indeed, State intervention is considered as "predatory" (Banda, 2011, p. 97). Consequently, we can derive a preference for commercial press and television, to the detriment of those party-oriented or state-controlled.

On the other hand, the social responsibility model views the media as a social institution, with the task of securing the access and the complete representation of different, cultural and political points of view (McQuail, 2000). Information is conceived as a public good, produced in the public sphere and aimed at influencing the formation of public opinion and public decisions. Therefore, we are dealing with a fundamental democratic right that must guarantee a model of equalitarian democracy. The role of the State is not demonized, because, in order to protect the plurality and diversity of opinions within a market's system, both state-controlled and commercial TV must coexist, subsidies are granted for the press as well as the right to reply and access for all social groups (such as ethnic, religious, political and linguistic minorities).

\section{Methodology}

The method used to analyse the indicators of Reporters without Borders and Freedom House has been a documentary analysis, paying special attention to the methodological modifications that have taken place in the reports, questionnaires and indexes used by these two organizations.

\footnotetext{
7 Hallin and Mancini (2012) define it as democratic corporatist model and identify also a pluralist-polarized model, which is a mixture of the elements of the other two models. For this reason, we take into account only the liberal and the democratic corporatist models.
} 
The monitoring and description of the changes, as well as the investigations derived from this type of indicators, allow us to draw trends in the representation of press freedom in the world and in the Latin American case in particular.

The study is based on the hypothesis that both the press freedom classification of RSF and that of FH penalizes the performance of the State as guarantor of the rights of citizens in general and of journalists in particular. Thus, some countries obtain more favourable positions that do not have to do directly with the situation of freedom of expression within their borders, but with instruments that benefit them in the ranking.

Faced with this difficulty in obtaining data and the relatively low academic interest in such a relevant issue in the configuration of media systems in democracy (United Nations, 2017a, 2017b), it is essential to define methodological strategies that make it possible to visualize the health status of press freedom in Latin America, the situation of the protection mechanisms of journalists and the effectiveness of the international effort to provide a critical multilateral apparatus to the security processes of information professionals.

\section{RESULTS}

\section{REPORTERS WITHOUT BORDERS}

In 1985, the non-profit organization Reporters Without Borders was founded in France. Currently, it is one of the best-known press freedom organizations in the world. Among its projects, the World Press Freedom Index stands out, an international ranking born in 2002 that scores countries taking into account different variables.

RSF has a methodology that has changed over the years. While in its classification of 2010 the organization sent a questionnaire to approximately 150 international experts, in which they were asked about 43 issues, in recent years this system has changed. If we stop at the methodology of this classification, the questions were divided into seven sections: 1. physical violence, 2. number of journalists killed, detained, physically attacked or threatened the role of the authorities in those cases, 3.Threats hints, harassment and access to information, 4 . censorship, and self-censorship, 5 . control of the media, 6 . judicial, financial pressures.

However, as stated by Sapiezynska and Lagos (2016, p. 554), "none of these sections included questions about the media ownership structure or about their economic concentration in private hands".

In fact, the questions in the section dedicated to "control of the media" merely referred to whether there were private media companies and whether they were "free to determine their editorial line". In this sense, it can be observed how RSF prioritized the evaluation of the State's restrictions on the freedom of expression over the consequences of media concentration or editorial limitations in certain private media.

In addition to excessive care over state control to guarantee the free market, attention is drawn to the reference made to violence and the number of journalists killed, detained or physically attacked. While it is true that in the Latin American case, this type 
of threat is due to a scenario of structural violence, the reality of the region is very diverse, and it seems to have more to do with dictatorial or failed regimes than with democratic countries.

A year later, the methodology of RSF underwent a strong modification, including more responses with negative points, which led to a change in the result of the best positioned ones that came to be below zero (such as the case of Finland and Norway, with scores of -10).

Likewise, the structure of the market and the analysis of pluralism of RSF again reflect a clear attention to the free market on the State's guarantee position: in question 37: [are there] serious threats to media diversity, above all as a result of media ownership being concentrated in few hands? Which of the following statements applies best to your country? Put a cross beside the statement that best matches the situation in your country:

1. Media pluralism is not in danger.

2. There are some threats or limitations to media pluralism.

3. Media pluralism exists, but is seriously threatened.

4. Media ownership is concentrated in very few hands and there is no pluralism. (RSF, 2012b, p. 7)

The problem that arises from the present analysis is the almost total absence of concern about the restrictions to freedom of information - because this is the preferred concept by both organizations - imposed by the market. If we refer to it in terms of state responsibility, it lies in the absence or weakness of laws and public policies to avoid the restrictions derived from the market. Again, this is an area not covered by the questionnaires (Sapiezynska \& Lagos, 2016).

Finally, it emphasizes that RSF omits the role of citizens as an active or passive agent of communication. Although they refer to the universality of press freedom, it is camouflaged by the market, without the guarantee given by a social responsibility model and even by a liberal model of information. The presence of a democratic constitutional state has been strongly defended not only by the UN and Unesco, but also by the Office of the Special Rapporteur for Freedom of Expression of the Ibero-American Commission on Human Rights.

The definition of values from o to 100 was used in the 2013 index and is maintained to this day. Thus, the best positioned countries are close to zero and the worst ones close to 100. Issues related to the safety of journalists and the issue of impunity, as well as the legal actions resulting from these have been omitted from the expert questionnaire and currently it is the RSF specialists who are responsible for collecting this data. Therefore, we observe an evolution in the methodological design that begins to become sophisticated through the juxtaposition of instruments.

The questionnaire, on the other hand, consisted of 74 questions divided into five thematic sections: 1. State of the media, 2. State of journalists, 3. Pluralism and editorial 
independence, 4. Law and application of law and 5. Internet and technical resources.

To calculate the results, RSF divided the questions again, this time into six criteria, assigning countries a score of o to 100 for each of them:

1. Pluralism, "measures the degree to which different opinions are represented in the media space" (Plu)

2. Independence of the media, "measures the ability of the media to function independently of the political, governmental, economic and religious powers" (Ind)

3. Environment and self-censorship, "analyzes the conditions under which information activities are carried out" (EnA indicator)

4. Legal framework, "Measures the performance of the legal framework that governs information activities" (CL)

5. Transparency, "measures the transparency of institutions and procedures that affect the production of information" (Tra)

6. Infrastructure, "Measures the quality of the infrastructure with which the production of information takes place" (Inf).

In the 2016 classification, a seventh indicator that refers specifically to the safety of journalists in the period taken into account is included:

7. Assaults, "Measures the intensity of violence in the observed period" (RSF, 2017) (Exa)

$$
S C O A=1 / 3 * P l u+1 / 6 *(\operatorname{Ind}+E n A+C L)+1 / 12 *(\operatorname{Tr} a+\operatorname{Inf})
$$

The second incorporating the levy, giving it a weight of $20 \%$ :

$$
S C O B=1 / 5 * E x a+4 / 15 * P l u+2 / 15 *(\operatorname{Ind}+\operatorname{EnA}+C L)+1 / 15 *(\operatorname{Tr} a+\operatorname{Inf}) .
$$

With respect to the calculation of the aggression score:

ScoreExa $=10 * \log \left(90 * n^{\circ}\right.$ killed + Coefficient $f_{i}^{*} n^{\circ}$ prisoners $+10 n^{\circ}$ kidnapped $+5 *$ $n^{\circ}$ attacks on the media $+3 * n^{\circ}$ exiled $+n^{\circ}$ arrests $+n^{\circ}$ aggressions)

The coefficient is calculated taking into account that the longer a journalist is imprisoned, the more responsibility will be given to the responsible country. Thus, the RSF calculates the coefficient in the following way.

\begin{tabular}{lccccccccccc}
\hline 1 & $1-$ & 2 & 3 & 4 & 5 & 6 & 7 & 8 & 9 & 10 & +10 \\
\hline Coefficient fi & 10 & 20 & 35 & 60 & 80 & 85 & 87 & 88 & 89 & 89,5 & $\operatorname{Lim}$ Coef $\mathrm{fi}=90$ \\
\hline
\end{tabular}

Table 1: Calculation of the aggression coefficient score.

$$
\text { Source: RSF (2017) }
$$

The final score is determined with the following formula:

$$
\text { Final score }=\max (\mathrm{SCOA}, \mathrm{sCOB}) \text {, }
$$


that is, selecting the highest of the two scores as the final score. These methodological changes irremediably influence the final classification and the value in the time of a number of Latin American countries. Despite these changes, the classification of Reporters Without Borders continues to benefit the role of the free market to the State in guaranteeing the rights of expression and freedom of information of citizens.

These types of issues can be evaluated by observing the last years of the global classification of RSF.

Of the nineteen countries analysed in Latin America ( 180 in total) for this study, RSF places the great majority in the second half of the table of its 2017 classification: Bolivia (107, score: 33,58), Brazil (103, score: 33.58), Colombia (129, score: 41,47), Cuba (173, score: 71,75$)$, Ecuador (105, score: 33,64), Guatemala (118, score: 39,33), Honduras (140, score: 43,75), Mexico (147, score: 48,97), Nicaragua (92, score: 31,01), Panama (96, score: 32,12$)$, Paraguay $(110$, score: 35,64$)$, Peru $(90$, score: 30,98$)$ and Venezuela $(137$, score: 42,94). Only Costa Rica $(6$, score: 11,93$)$, Uruguay $(25$, score: 17,43$)$, Chile $(33$, score: 20,53), Argentina (50, score: 25,07), Dominican Republic (59, score: 26,76$)$ and El Salvador $(62$, score: 27,24$)$ were in superior positions (Table 2).

\begin{tabular}{lll}
\hline & PosITION & \multicolumn{1}{c}{ SCORE } \\
\hline Argentina & 50 & 25,07 \\
\hline Bolivia & 107 & 33,58 \\
\hline Brazil & 103 & 33,58 \\
\hline Chile & 33 & 42,94 \\
\hline Colombia & 129 & 41,47 \\
\hline Costa Rica & 6 & 11,93 \\
\hline Cuba & 173 & 71,75 \\
\hline Ecuador & 105 & 33,64 \\
\hline El Salvador & 62 & 27,24 \\
\hline Guatemala & 118 & 39,33 \\
\hline Honduras & 140 & 43,75 \\
\hline México & 147 & 48,97 \\
\hline Nicaragua & 92 & 31,01 \\
\hline Panamá & 96 & 32,12 \\
\hline Paraguay & 110 & 35,64 \\
\hline Peru & 90 & 30,98 \\
\hline Doinican Republic & 59 & 26,76 \\
\hline Uruguay & 25 & 17,43 \\
\hline Venezuela & 137 & 42,94 \\
\hline
\end{tabular}


However, remember that these countries have a great differentiation between them and with critical situations in some nations determined by the multiplicity of perpetrators, the insecurity of information professionals and a scenario of permanent impunity that perpetuates these conditions of vulnerability. Mexico, Colombia, Honduras, Brazil and Guatemala are the most dangerous countries for professional practice during the first 17 years of $21^{\text {st }}$ century.

To cite the most extreme example, Mexico is perpetuated as the most dangerous country to practice journalism in the region (González de Bustamante \& Relly 2017, 2016; Hughes \& Márquez Ramírez, 2017), with 163 journalists killed in these 17 years, in addition to other types of violence, and in the classification of RSF appears ahead of other countries in the region such as Cuba, where there has been no death.

Since 2006, the number of information professionals murdered in Mexico has increased considerably, coinciding with the fight against drug trafficking (Relly \& González de Bustamante, 2014, 2017). The creation of the Special Prosecutor's Office for the Attention of Crimes against Freedom of Expression (FEADLE, in Spanish) and in 2012 of a protection mechanism for human rights defenders and journalists have not improved this situation. In fact, several organizations have denounced that "effective assistance is not provided to journalists at risk" and demand that "prevention be strengthened to avoid lethal attacks" (CP), 2017, p. 37).

With 57 victims, Brazil is the fourth country with the most journalists murdered in Latin America. Political changes in recent years and citizen protests have been widely addressed in public, private and community media, increasing the vulnerability of information professionals. The year 2015 was particularly noteworthy, since nine information professionals died. Reporters Without Borders promoted the campaign during the 2016 Olympic Games called "some victories do not deserve a medal", in which it denounced the cases of Brazilian journalists killed in the exercise of their professional work. Among them, RSF recalled Gleydson Carvalho, a journalist who was killed when unknown persons shot him in the Radio Libertade FM 90.3 studios in Camocim, in the state of Ceará, on August 6, 2015. Another case highlighted in this campaign is that of the journalist Pedro Palma, director of the weekly Regional Panorama, murdered at his home on February 13, 2014, for having reported corruption cases of officials in Rio de Janeiro (Díaz Nosty $\&$ de Frutos, 2017).

\section{FreEdom House}

The evaluation of the methodology of Freedom House, an organization born in the United States in 1941, has made it possible to identify clear inconsistencies between the opinions of the organization and the application of the indicators. FH refers to the Article 19 of the Universal Declaration of Human Rights that states that "everyone has the right to freedom of opinion and expression". Hence, theoretically freedom of information is conceived as a basic human right that every state must protect. However, the measurement process of $\mathrm{FH}$ does not respond to the universality of the human right and 
to the State as guarantor of this universality, but refers to it as an individual right, mainly framed in economic terms.

Freedom House categorizes the countries into three main categories taking into account a scale that ranges from the best score (0) to the worst (100), based on 23 questions and 109 indicators divided into three broad categories: the legal environment, the political environment, and the economic environment.

Freedom House's methodology, far from evaluating freedom of expression, focuses on freedom of the press and even more so on the freedom of private media owners, in detriment to the rights of journalists and ignoring citizens, the holders of the right to freedom of expression. Its questionnaire seeks to discover, in the first place, the extent to which states "interfere" in the freedom of private media companies, and in second place, the physical attacks and legal and governmental constraints against journalists. Restrictions on the freedom of expression, information, or communication in the media by private actors - and not just the state - are included, but minimally and with scant weight in the methodology. (Sapiezynska \& Lagos, 2016, p. 564)

As has already been demonstrated in a previous study (Giannone, 2014), from the birth of the instrument in 1979, a number of important methodological changes have been made on the Freedom of the Press Index. In 1994, a 100-point scale was introduced, joining the pre-existing labelling system ("free", "partially free", "not free" press countries). While the latter just allowed to divide countries into three categories, the rating system brought to the creation of annual global rankings of freedom of information, thus enabling the comparability of countries within each category, and constituting a pressure for countries to improve their performance. Another methodological change was introduced in 1989. Up to 1988, the instrument provided two distinct indices of freedom, one for the press and a different one for the radio-TV system. The two systems were unified from 1989 to 1993. Then, from 1994 to 2001, after the introduction of the scoring system, the FPI provided one total score and eight sub-scores (four for the print and four for broadcast), concerning respectively the legal, political, and economic environment, and repressive actions ${ }^{8}$. As Karlekar Deutsch and Radsch pointed out $(2012$, p. 15), the methodology was "substantially revamped" in 2002. In the first place, the distinction between print and broadcast was deleted again. In the second place, the 'repressive actions' category was eliminated, and its score was attributed to the 'political environment' category, since then accounting for 40 of the 100 points allocated in the survey methodology. This change was justified by the fact that controlling the power of framing messages as news "has been the policy of repressive governments ever since the introduction of broadcasting" (Karlekar Deutsch \& Radsch, 2012, p. 15). Since the 'political environment' is concerned with the role of government in the ownership, regulation and control of media

${ }^{8}$ For detailed data (1980-2017) and changes in sub-scores over the period 1994-2001, see https://freedomhouse.org/sites/ default/files/FOTP1980-FOTP2017_Public-Data.xlsx (accessed 14 November 2017). 
systems, "the $\mathrm{FH}$ assumes that such role is more important than the role of private corporations (the economic environment, scored up to 30 points) or legal provisions (up to 30 points) in influencing freedom of information" (Giannone, 2014, p. 517).

In recent years the questionnaire of the US organization has suffered "minor but significant changes". To cite some of the most characteristic, as of 2011 , the word bloggers was introduced in some of the questions, along with professional journalists. The instructions to answer another question indicates that the interviewee should "consider written, audiovisual and internet media". Freedom House included these changes in response to criticism of its exclusive focus on traditional media and disdain for digital media (Burgess, 2010). Despite these changes, the FH continues to support the possibility of comparing the data covering the whole reference period (Freedom House, 2012).

As far as the safety of media practitioners is concerned, the FPI contains two methodology questions dedicated to this issue, both included in the "political environment" category. The first one, ranging from o to 6 points, is: "are both local and foreign journalists able to cover the news freely and safely in terms of physical access and on-theground reporting?". The second question, ranging from o to 10 points, is "are journalists, bloggers, or media outlets subject to extralegal intimidation or physical violence by state authorities or any other actor as a result of their reporting?". Hence, the weight of the safety of journalists on the instrument is $16 \%$. Both questions are coupled with a note, introduced in the last issue of the instrument, that specifies that the "question applies to conditions experienced by journalists, bloggers, or media outlets during the course of their work" (Freedom House, 2017a). However, this is only the last version of the questions. As shown by a longitudinal analysis (see Table 3), from 2009 to date these two questions, and their indicators, underwent several changes.

\begin{tabular}{|c|c|c|c|c|}
\hline & 2009 & 2013 & 2016 & 2017 \\
\hline Question 6 & $\begin{array}{l}\text { Are both local and fo- } \\
\text { reign journalists able to } \\
\text { cover the news freely? }\end{array}$ & $\begin{array}{l}\text { Are both local and } \\
\text { foreign journalists } \\
\text { able to cover the } \\
\text { news freely in terms } \\
\text { of harassment and } \\
\text { physical access? }\end{array}$ & $\begin{array}{l}\text { Are both local and foreign } \\
\text { journalists able to cover the } \\
\text { news freely and safely in } \\
\text { terms of physical access and } \\
\text { on-the-ground reporting? }\end{array}$ & $\begin{array}{l}\text { Are both local and foreign } \\
\text { journalists able to cover the } \\
\text { news freely and safely in } \\
\text { terms of physical access and } \\
\text { on-the-ground reporting? }\end{array}$ \\
\hline \multirow[t]{4}{*}{$\begin{array}{l}\text { Indicators of } \\
\text { question } 6\end{array}$} & $\begin{array}{l}\text { Are journalists } \\
\text { harassed while } \\
\text { covering the news? }\end{array}$ & $\begin{array}{l}\text { Are journalists } \\
\text { harassed while } \\
\text { covering the news? }\end{array}$ & $\begin{array}{l}\text { To what extent are journalists } \\
\text { harassed or attacked while } \\
\text { attempting to gather news } \\
\text { or cover events in person? }\end{array}$ & $\begin{array}{l}\text { To what extent are journalists } \\
\text { harassed or attacked while } \\
\text { attempting to gather news } \\
\text { or cover events in person? }\end{array}$ \\
\hline & $\begin{array}{l}\text { Are certain geogra- } \\
\text { phical areas of the } \\
\text { country off-limits } \\
\text { to journalists? }\end{array}$ & $\begin{array}{l}\text { Are certain geogra- } \\
\text { phical areas of the } \\
\text { country off-limits } \\
\text { to journalists? }\end{array}$ & $\begin{array}{l}\text { Are certain geographical } \\
\text { areas of the country off- } \\
\text {-limits to journalists? }\end{array}$ & $\begin{array}{l}\text { Are certain geographical } \\
\text { areas of the country off- } \\
\text {-limits to journalists? }\end{array}$ \\
\hline & $\begin{array}{l}\text { Does a war, insurgency, } \\
\text { or similar situation in } \\
\text { a country inhibit the } \\
\text { operation of media? }\end{array}$ & $\begin{array}{l}\text { Does a war, insurgen- } \\
\text { cy, or similar situation } \\
\text { in a country inhibit the } \\
\text { operation of media? }\end{array}$ & $\begin{array}{l}\text { Does a war, insurgency, or } \\
\text { similar situation in a country } \\
\text { inhibit the operation of media? }\end{array}$ & $\begin{array}{l}\text { Does a war, insurgency, or } \\
\text { similar situation in a country } \\
\text { inhibit the operation of media? }\end{array}$ \\
\hline & & & $\begin{array}{l}\text { Do authorities require } \\
\text { journalists working in danger } \\
\text { zones to be "embedded"? }\end{array}$ & $\begin{array}{l}\text { Do authorities require } \\
\text { journalists working in danger } \\
\text { zones to be "embedded"? }\end{array}$ \\
\hline
\end{tabular}




\begin{tabular}{|c|c|c|c|c|}
\hline & $\begin{array}{l}\text { Is there surveillance } \\
\text { of foreign journalists } \\
\text { working in the country? }\end{array}$ & $\begin{array}{l}\text { Is there survei- } \\
\text { Ilance of foreign } \\
\text { journalists working } \\
\text { in the country? }\end{array}$ & $\begin{array}{l}\text { Is there surveillance } \\
\text { of foreign journalists } \\
\text { working in the country? }\end{array}$ & $\begin{array}{l}\text { Is there surveillance } \\
\text { of foreign journalists } \\
\text { working in the country? }\end{array}$ \\
\hline & $\begin{array}{l}\text { Are foreign journalists } \\
\text { inhibited or barred } \\
\text { by the need to secure } \\
\text { visas or permits to } \\
\text { report or to travel } \\
\text { within the country? }\end{array}$ & $\begin{array}{l}\text { Are foreign journalists } \\
\text { inhibited or barred } \\
\text { by the need to secure } \\
\text { visas or permits to } \\
\text { report or to travel } \\
\text { within the country? }\end{array}$ & $\begin{array}{l}\text { Are foreign journalists inhibited } \\
\text { or barred by the need to secure } \\
\text { visas or permits to report from } \\
\text { or travel within the country? }\end{array}$ & $\begin{array}{l}\text { Are foreign journalists inhibited } \\
\text { or barred by the need to secure } \\
\text { visas or permits to report from } \\
\text { or travel within the country? }\end{array}$ \\
\hline & $\begin{array}{l}\text { Are foreign journalists } \\
\text { deported for repor- } \\
\text { ting that challenges } \\
\text { the regime or other } \\
\text { powerful interests? }\end{array}$ & $\begin{array}{l}\text { Are foreign journalists } \\
\text { deported for reporting } \\
\text { that challenges the } \\
\text { regime or other } \\
\text { powerful interests? }\end{array}$ & $\begin{array}{l}\text { Are foreign journalists } \\
\text { deported for reporting that } \\
\text { challenges the authorities or } \\
\text { other powerful interests? }\end{array}$ & $\begin{array}{l}\text { Are foreign journalists } \\
\text { deported for reporting that } \\
\text { challenges the authorities or } \\
\text { other powerful interests? }\end{array}$ \\
\hline & 2009 & 2013 & 2016 & 2017 \\
\hline Question 7 & $\begin{array}{l}\text { Are journalists or me- } \\
\text { dia outlets subject to } \\
\text { extra-legal intimidation } \\
\text { or physical violence } \\
\text { by state authorities } \\
\text { or any other actor? }\end{array}$ & $\begin{array}{l}\text { Are journalists, } \\
\text { bloggers, or media } \\
\text { outlets subject to } \\
\text { extralegal intimidation } \\
\text { or physical violence } \\
\text { by state authorities } \\
\text { or any other actor? }\end{array}$ & $\begin{array}{l}\text { Are journalists, bloggers, } \\
\text { or media outlets subject to } \\
\text { extralegal intimidation or } \\
\text { physical violence by state } \\
\text { authorities or any other actor } \\
\text { as a result of their reporting? }\end{array}$ & $\begin{array}{l}\text { Are journalists, bloggers, } \\
\text { or media outlets subject to } \\
\text { extralegal intimidation or } \\
\text { physical violence by state } \\
\text { authorities or any other actor } \\
\text { as a result of their reporting? }\end{array}$ \\
\hline \multirow[t]{6}{*}{$\begin{array}{l}\text { Indicators of } \\
\text { question } 7\end{array}$} & $\begin{array}{l}\text { Are journalists subject } \\
\text { to murder, injury, ha- } \\
\text { rassment, threats, ab- } \\
\text { duction, expulsion, ar- } \\
\text { bitrary arrest and illegal } \\
\text { detention, or torture? }\end{array}$ & $\begin{array}{l}\text { Are journalists or } \\
\text { bloggers subject to } \\
\text { murder, injury, harass- } \\
\text { ment, threats, abduc- } \\
\text { tion, expulsion, arbi- } \\
\text { trary arrest and illegal } \\
\text { detention, or torture? }\end{array}$ & $\begin{array}{l}\text { Are journalists or bloggers } \\
\text { subject to murder, injury, } \\
\text { harassment, threats, abduction, } \\
\text { arbitrary arrest and illegal de- } \\
\text { tention, or torture in retaliation } \\
\text { for their professional activities? }\end{array}$ & $\begin{array}{l}\text { Are journalists or bloggers } \\
\text { subject to murder, injury, ha- } \\
\text { rassment, threats, abduction, } \\
\text { arbitrary arrest and illegal de- } \\
\text { tention, or torture in retaliation } \\
\text { for their professional activities? }\end{array}$ \\
\hline & & & $\begin{array}{l}\text { Do journalists face reprisals } \\
\text { in the form of trumped-up } \\
\text { criminal charges with no } \\
\text { explicit link to their work, such } \\
\text { as weapons possession, drug } \\
\text { possession, or tax evasion? }\end{array}$ & $\begin{array}{l}\text { Do journalists face reprisals } \\
\text { in the form of trumped-up } \\
\text { criminal charges with no } \\
\text { explicit link to their work, such } \\
\text { as weapons possession, drug } \\
\text { possession, or tax evasion? }\end{array}$ \\
\hline & $\begin{array}{l}\text { Do armed militias, } \\
\text { organized crime, } \\
\text { insurgent groups, } \\
\text { political or religious } \\
\text { extremists, or other } \\
\text { organizations regularly } \\
\text { target journalists? }\end{array}$ & $\begin{array}{l}\text { Do armed militias, } \\
\text { organized crime, } \\
\text { insurgent groups, } \\
\text { political or religious } \\
\text { extremists, or other } \\
\text { organizations regular- } \\
\text { ly target journalists? }\end{array}$ & $\begin{array}{l}\text { Do armed militias, organized } \\
\text { crime, insurgent groups, } \\
\text { political or religious extre- } \\
\text { mists, or other organizations } \\
\text { regularly target journalists } \\
\text { in response to their work? }\end{array}$ & $\begin{array}{l}\text { Do armed militias, organized } \\
\text { crime, insurgent groups, } \\
\text { political or religious extre- } \\
\text { mists, or other organizations } \\
\text { regularly target journalists } \\
\text { in response to their work? }\end{array}$ \\
\hline & $\begin{array}{l}\text { Have journalists } \\
\text { fled the country or } \\
\text { gone into hiding to } \\
\text { avoid such action? }\end{array}$ & $\begin{array}{l}\text { Have journalists } \\
\text { fled the country or } \\
\text { gone into hiding to } \\
\text { avoid such action? }\end{array}$ & $\begin{array}{l}\text { Have journalists fled the coun- } \\
\text { try or gone into hiding or exile } \\
\text { to avoid such repercussions? }\end{array}$ & $\begin{array}{l}\text { Have journalists fled the coun- } \\
\text { try or gone into hiding or exile } \\
\text { to avoid such repercussions? }\end{array}$ \\
\hline & & & $\begin{array}{l}\text { Do journalists under threat } \\
\text { from nonstate actors re- } \\
\text { ceive adequate protection } \\
\text { from state authorities? }\end{array}$ & $\begin{array}{l}\text { Do journalists under threat } \\
\text { from nonstate actors re- } \\
\text { ceive adequate protection } \\
\text { from state authorities? }\end{array}$ \\
\hline & $\begin{array}{l}\text { Have media compa- } \\
\text { nies been targeted for } \\
\text { physical attack or for } \\
\text { the confiscation or des- } \\
\text { truction of property? }\end{array}$ & $\begin{array}{l}\text { Have media compa- } \\
\text { nies been targeted } \\
\text { for physical attack } \\
\text { or for the confisca- } \\
\text { tion or destruction } \\
\text { of property? }\end{array}$ & $\begin{array}{l}\text { Have media companies been } \\
\text { targeted for physical attack } \\
\text { or for the confiscation or } \\
\text { destruction of property? }\end{array}$ & $\begin{array}{l}\text { Have media companies been } \\
\text { targeted for physical attack } \\
\text { or for the confiscation or } \\
\text { destruction of property? }\end{array}$ \\
\hline
\end{tabular}




\begin{tabular}{lll}
\hline & Are there technical atta- & $\begin{array}{l}\text { Are there technical atta- } \\
\text { cks - such as hacking or } \\
\text { distributed denial-of-service } \\
\text { tacks on news and in- }\end{array}$ \\
formation websites or & (DDoS) attacks - on news & (DDoS) attacks - on news \\
key online outlets for & outlets' websites or on social- & outlets' websites or on \\
information exchange? & -media accounts that are used & social-media accounts that are \\
to disseminate news? & & used to disseminate news?
\end{tabular}

Table 3: The safety of media practitioners according to Freedom House

The changes are both formal and substantial, as some indicators have been introduced from 2016 and others have been radically modified. These changes reflect FH's intention to refine the field of investigation of such a controversial issue: therefore, it is important the introduction of an indicator about the threat to journalists from non-state actors and the adequate protection from state authorities. And it is also important to take into account the issue of "embedded journalism" in dangerous zones. However, these modifications put into question the comparability of data over time, as well as the validity and reliability of the instrument. Indeed, the introduction of two notes for the questions in the 2017 version reveal a possible difficulty of the survey team in detecting the issue.

Although they are working for refining their instruments, both FH and RSF are still distant from the use of stricter descriptors of the journalistic profession such as those used by Unesco itself. Taking as reference the decision adopted by the Council of the International Program for the Development of Communication (IPDC) in 2014 and defined in the Journalists' Security Indicators: National Level, it is considered a "journalist" and, therefore, units of analysis for the present article, "journalists, media workers and social media producers that generate a significant volume of journalistic activity of public interest" (Unesco, 2013, p.2):

journalists are people who observe, describe, document and analyse events and document and analyse statements, policies and any proposal that may affect society, in order to systematize that information and gather facts and analysis to inform the sectors of the society or the society as a whole. (Unesco, 2012, p. 3)

The specialists chosen by $\mathrm{FH}$ analyse the results of each indicator and question and categorize the countries in three big labels in the press freedom country status: "free", "partially free" or "not free".

Of the 199 countries and territories assessed for 2016, a total of 61 (31 percent) were rated Free, 72 ( 36 percent) were rated Partly Free, and 66 (33 percent) were rated Not Free. In the case of the Latin American States studied, in 2017 four of them were considered "not free" (Cuba, with a score of 91, Honduras, 66, México, 64, and Venezue$\mathrm{la}, 81$ ) and the rest were divided into "partially free" (Argentina, 46; Bolivia, 53; Brazil, 47; Colombia, 57; El Salvador, 41; Guatemala, 58; Nicaragua, 55; Panamá, 41; Peru, 42, and Dominican Republic, 42) while three were considered "free" (Chile, 29; Costa Rica, 16 and Uruguay, 24) (Table 4). 


\begin{tabular}{|c|c|c|c|c|c|}
\hline & $\begin{array}{l}\text { Press Free- } \\
\text { dom Status }\end{array}$ & $\begin{array}{l}\text { PRESS FrEEDOM } \\
\text { SCORE } \\
(0-100 \text { POINTS })\end{array}$ & $\begin{array}{c}\text { LEGAL } \\
\text { ENVIRONMENT } \\
\text { (0-30 POINTS) }\end{array}$ & $\begin{array}{c}\text { PolITICAL } \\
\text { ENVIRONMENT } \\
(0-40)\end{array}$ & $\begin{array}{c}\text { ECONOMIC } \\
\text { ENVIRONMENT } \\
(0-30=\end{array}$ \\
\hline Argentina & Partly Free & 46 & 13 & 18 & 15 \\
\hline Bolivia & Partly Free & 53 & 16 & 23 & 14 \\
\hline Brazil & Partly Free & 47 & 14 & 22 & 11 \\
\hline Chile & Free & 29 & 8 & 13 & 8 \\
\hline Colombia & Partly Free & 57 & 13 & 26 & 18 \\
\hline Costa Rica & Free & 16 & 4 & 6 & 6 \\
\hline Cuba & Not Free & 91 & 28 & 35 & 28 \\
\hline Ecuador & Not Free & 66 & 23 & 27 & 16 \\
\hline El Salvador & Partly Free & 41 & 10 & 18 & 13 \\
\hline Guatemala & Partly Free & 58 & 18 & 23 & 17 \\
\hline Honduras & Not Free & 66 & 18 & 33 & 15 \\
\hline México & Not Free & 64 & 19 & 31 & 14 \\
\hline Nicaragua & Partly Free & 55 & 14 & 24 & 17 \\
\hline Panamá & Partly Free & 41 & 17 & 15 & 9 \\
\hline Paraguay & Partly Free & 59 & 16 & 24 & 19 \\
\hline Peru & Partly Free & 45 & 14 & 19 & 12 \\
\hline Doinican Republic & Partly Free & 42 & 8 & 21 & 13 \\
\hline Uruguay & Free & 24 & 6 & 10 & 8 \\
\hline Venezuela & Not Free & 81 & 26 & 31 & 24 \\
\hline
\end{tabular}

Table 4: Freedom of the Press 2017. Table of Latin American Country scores

The pattern of extreme violence against journalists in several Latin American countries continued unabated in 2016 (FH, 2017b). Brazil, Colombia, Honduras, and Mexico remain among the world's most dangerous places for journalists, and all face ongoing challenges in investigating and prosecuting these crimes. The number of murders in Mexico rose, according to some sources, especially for reporters covering police abuses, drug trafficking, and governmental corruption. While El Salvador has traditionally had less violence against journalists despite its high overall homicide rate, intimidation of the media has increased there as well. Protection mechanisms have been put in place in a number of countries, but their effectiveness is still limited by problems such as bureaucratic rivalries, insufficient funding, and lack of training (Freedom House, 2017b, p. 21)

\section{Conclusions}

The analyses of press freedom in the world and in Latin America in general are extremely complex and deserve a detailed analysis of the instruments we use to measure them. The Freedom House and Reporters without Borders classifications have traditionally been used to represent the situation of different countries in this area but present serious methodological problems. 
In the first place, the present investigation has allowed affirming that the indicators suffer from deficiencies that make difficult the characterization of concrete realities, such as those of the Latin American region, characterized by a high degree of violence in certain countries and with different social and democratic systems of law.

In this sense, both RSF and FH penalize the State's regulatory apparatus to protect the rights of citizens and make invisible the work of Latin Americans in transcending from mere passive agents to active agents of communication, benefiting private corporations in their scores.

Although RSF and $\mathrm{FH}$ start from the universal vision of human rights in general and freedom of the press in particular, they reduce it to the free market and, thereby, diminish the very idiosyncrasy of fundamental rights.

\section{BIBLIOGRAPHIC REFERENCES}

Banda, F. (2011). What are we measuring? A critical review of media development assessment tools. In M.E. Price, S. Abbott \& L. Morgan L (Eds.), Measures of press freedom and media contributions to development. Evaluating the evaluators (pp. 89-107). New York: Peter Lang.

Badran M. (2017). Violence against journalists: suppressing media freedom. In M. Friedrichsen \& Y. Kamalipour (Eds.), Digital transformation in journalism and news media. Media business and innovation (pp. 417-427). Cham, Switzerland: Springer.

Becker, J. (2003). Review article: keeping track of press freedom. European Journal of Communication, 18(1), 107-12.

Becker, L. B., Vlad, T. \& Nusser, N. (2007). An evaluation of press freedom indicators. The International Communication Gazette, 69(1), 5-28.

Brunetti A. \& Weder B. (2003). A free press is bad news for corruption. Journal of Public Economics, 87, 1801-24.

Burgess, J. (2010). Evaluating the evaluators: media freedom indexes and what they measure. Washington, D.C.: Center for International Media Assistance at the National Endowment for Democracy.

Chomsky, N. \& Herman, E. S. (1988). Manufacturing consent. The political economy of the mass-media. New York: Pantheon Books.

Comité para la Protección de los Periodistas (CPJ) (2017). Sin excusa: México debe quebrar el ciclo de impunidad en asesinatos de periodistas. Ciudad de México: $\mathrm{CPJ}$.

Dahl, R. A. (2003). How democratic is the American constitution? Yale: Yale University Press.

Díaz Nosty, B. \& de Frutos García, R. (2017). Asesinatos, hostigamientos y desapariciones. La realidad de los periodistas latinoamericanos en el s. XXI. Revista Latina de Comunicación Social, 72, 1.418-1.434.

Díaz Nosty, B. (2016a). Periodismo muerto. Más de mil periodistas asesinados en América Latina (1970-2015). Ciudad de México: Planeta Editorial.

Díaz Nosty, B. (2016b). Medio siglo de atentados contra periodistas. Infoamérica. Revista Iberoamericana de Comunicación, 10, 87-113. 
Freille S., Haque M. E. \& Kneller R. (2007). A contribution to the empirics of press freedom and corruption. European Journal of Political Economy, 23(4), 838-862.

Freedom House (2012). Checklist of methodology questions 2012. Retrieved from www.freedomhouse.org

Freedom House (2017a). Freedom of the press 2017 methodology. Retrieved from https://www.ifex.org/ international/2017/11/17/un-resolutions-safety- journalists/https://freedomhouse.org/report/ freedom-press-2017-methodology.

Freedom House (2017b). Freedom of the press. Press freedom's dark horizon. Retrieved from https:// freedomhouse.org/sites/default/files/FOTP_2017_booklet_FINAL_April28.pdf

Frutos, R. (2014). Indicadores mediáticos: análisis crítico de los modelos de evaluación internacional. Doctoral thesis, Universidade de Málaga, Málaga, Espanha.

Giannone D. (2010). Political and ideological aspects in the measurement of democracy: the Freedom House Case. Democratization 17(1), 68-97.

Giannone, D. (2014). The political and ideological dimension of the measurement of freedom of information. Assessing the interplay between neoliberalism and the Freedom of the Press Index. International Communication Gazette, 76(6), 505-527.

Giannone, D. \& De Frutos, R. (2016). Measuring freedom of information: issues and opportunities from an expert survey. International Journal of Communication, 10, 589-619.

González de Bustamante, C. \& Relly J. E. (2014). Journalism in times of violence: Social media use by US and Mexican journalists working in northern Mexico. Digital Journalism, 2, 507-523.

González de Bustamante C., \& Relly J. E. (2016). Professionalism under threat of violence: journalism, reflexivity, and the potential for collective professional autonomy in northern Mexico. Journalism Studies, 17, 684- 702 .

Gunther R. \& Mughan A. (Eds.) (2000). Democracy and the media: a comparative perspective. Cambridge: Cambridge University Press.

Hallin D. C. \& Mancini P. (2012). Comparing media systems beyond the western world. New York: Cambridge University Press.

Holtz-Bacha C. (2011). Freedom of the press: is a worldwide comparison possible and what is it good for? In M. E. Price, S. Abbott \& L. Morgan (Eds.), Measures of press freedom and media contributions to development. Evaluating the evaluators (129-143). New York: Peter Lang.

Hughes, S. \& Márquez-Ramírez, M. (2017). Examining the practices that mexican journalists employ to reduce risk in a context of violence. International Journal of Communication, 11(23) 499-521.

Hughes S., Mellado C., Arroyave J., Benitez J. L., de Beer A., Garcés M. \& Márquez-IFEX (2017). How can UN resolutions make it safer to be a journalist? Retrieved from https://www.ifex.org/ international/2017/11/17/un-resolutions-safety- journalists

Karlekar Deutsch K. \& Radsch C. (2012). Adapting concepts of media freedom to a changing media environment: incorporating new media and citizen journalism into the Freedom of the Press Index. ESSACHESS. Journal for Communication Studies 5(9), 13-22.

Kaufmann D. (2005). Human rights and governance: the empirical challenge. In P. Alston \& M. Robinson (Eds.), Human rights and development: towards mutual reinforcement (pp. 352-402). New York: Oxford University Press. 
McQuail, D. (2000). McQuail's mass communication theory. London: Sage.

Mirowski, P. (2011). Science-mart. Privatizing American science. Cambridge: Harvard University Press.

Norris P. (2006). The role of the free press in promoting democratization, good governance, and human development. In Unesco meeting on World Press Freedom Day: media, development, and poverty eradication, Colombo, Sri Lanka, 1-2 May.

Ramírez M. (2017). Expanding influences research to insecure democracies: how violence, public insecurity, economic inequality and uneven democratic performance shape journalists' perceived work environments. Journalism Studies, 18, 645-665.

Relly J. E. \& González de Bustamante, C. (2014). Silencing Mexico: A study of influences on journalists in the northern states. The International Journal of Press/Politics, 19, 108-131.

Relly J. E. \& González de Bustamante, C. (2017). Global and domestic networks advancing prospects for institutional and social change: the collective action response to violence against journalists. The International Journal of Press/Politics, 19, 108-131.

Reporters without Borders (RWB) (2017). Clasificación de la libertad de prensa en el mundo. Retrieved from https://www.rsf-es.org/grandes-citas/clasificacion-por-paises/

Sapiezynska, E. \& Lagos, C. (2016). Media freedom indexes in democracies: a critical perspective through the cases of Poland and Chile. International Journal of Communication, 10, 549-570.

Scoble H. M. \& Wiseberg L. S. (1981). Problems of comparative research on human rights. In V. P. Nanda, J. R. Scarritt \& G. W. Jr Shepherd (Eds.), Global human rights: public policies, comparative measures, and NGO strategies (pp. 147-17). Boulder, CO: Westview Press.

Siebert F. R., Peterson T. \& Schramm W. (1956). Four theories of the press. Urbana: University of Illinois Press.

Sobel R. S., Dutta N. \& Roy S. (2011). Beyond borders: Is media freedom contagious? In M. E. Price, S.Abbott $\&$ L. Morgan (Eds.), Measures of press freedom and media contributions to development. Evaluating the evaluators (pp. 307-320). New York: Peter Lang.

Tran H., Mahmood R., Du, Y. \& Khrapavitski A. (2011). Linking measures of global press freedom to development and culture: implications from a comparative analysis. International Journal of Communication, 5, 170-191.

Unesco (2012). UN Plan of Action on the Safety of Journalists and the Issue of Impunity. Retrieved from http:// www.unesco.org/new/fileadmin/MULTIMEDIA/HQ/CI/Cl/pdf/official_documents/UN-Plan-on-SafetyJournalists_EN_UN-Logo.pdf

Unesco (2013). Journalists' Safety Indicators:National Level. Based on the Unesco's Media Development Indicators. Retrieved from http://www.unesco.org/fileadmin/MULTIMEDIA/HQ/CI/CI/pdf/official_ documents/Journalists_Safety_Indicators_National_Level.pdf

Unesco (2016). Time to break the cycle of violence against journalists. Highlights from the Unesco DirectorGeneral'S 2016 report on safety of journalists and the danger of impunity. Retrieved from https:// en.unesco.org/sites/default/files/unesco_report_english_rgb.pdf

Unesco \& Reporters Without Borders (2013). Safety guide for journalists. A handbook for reporters in high-risk environments. Retrieved from http://unesdoc.unesco.org/images/0024/002439/243988s.pdf

United Nations (2016, February 10). La seguridad de las periodistas y la questión de la Impunidad. Resolución 70/162. Retrieved from http://www.un.org/es/comun/docs/?symbol=A/RES/70/162 
United Nations (2017a). Multi-stakeholder consultation on strengthening the implementation of the UN plan of action on the safety of journalists and the issue of impunity. Retrieved from https://en.unesco.org/sites/ default/files/concept_note_multi-stakeholder_consultation_en.pdf

United Nations (2017b, August). La seguridad de las periodistas y la cuestión de la impunidad. Informe del Secretario General de Naciones Unidas.

United Nations Development Programme (UNDP) (2004). Governance Indicators: A Users' Guide. Retrieved from https://tinyurl.com/79dhnfz

Van Belle, D. A. (1997). Press freedom and the democratic peace. Journal of Peace Research, 34(4), $405-414$.

Voltmer K. (2013). The Media in transitional democracies. Cambridge: Polity Press.

\section{BIOGRAPHICAL NOTES}

Ruth de Frutos coordinates the Chair Unesco in Communication at the University of Malaga, Spain.

E-mail: ruth.defrutos@uma.es

Address: University of Malaga, Malaga, 29071 Spain

Diego Giannone is a Professor of the Department of Political Science "Jean Monnet" of the Università della Campania "Luigi Vanvitelli", Italy

E-mail: diego.GIANNONE@unicampania.it

Address: Department of Political Science "Jean Monnet" of the Università della Campania "Luigi Vanvitelli". Viale Ellittico, 31 - 81100 Caserta, Italy

* Submitted: 30.11 .2017

* Accepted: 15.03.2018 